\title{
Appraisal of the Salam Islamic Mode of Financing Agribusiness and Agriculture among Rural Farmers in Bauchi State of Nigeria
}

\author{
Hashim Sabo Bello
}

$\mathrm{PhD}$, Department of Business Administration and Management, School of Management Sciences, Abubakar Tatari Ali Polytechnic Bauchi, Bauchi State, Nigeria

Ibrahim Suleiman Galadima

Department of Islamic Studies, A.D. Rufa'I College of Legal and Islamic Studies, Misau, Bauchi State, Nigeria

\section{Al-Mustapha Adopu Jibrin}

MSc Student, Animal Health \& Production, Department of Animal Production, Abubakar Tafawa Balewa University, Bauchi, Nigeria

\begin{abstract}
The study focuses on the socio-economic characteristics of the rural farmers in order to relate the viability of an alternative ethical financing and investment in the quest for economic self-reliance and sufficiency in the study area. The study attempts to examine the influence of perceptions, attitudes, religious belief, and subjective norm on farmers' patronage of Islamic mode of financing agribusiness and agriculture. No study of this nature was found by these researchers in Bauchi State. The study adopted a survey method in which 150 questionnaires were administered to rural farmers, 118 were returned. The study employed the use of multiple regressions using STATA software. Although findings revealed that there is a positive relationship between farmers' perception of Salam on agribusiness and agriculture, but there is no influence between perception of Salam and agribusiness efficiency and agricultural productivity. Results also showed positive relationship between the roles of Bai' Salam (Forward Sale Financing) Islamic mode of financing and the agribusiness efficiency and agricultural productivity, of which if properly harnessed will go a long way to ensure the practicability of new agricultural ethical finance and as well accelerate the viability of agribusiness efficiency and agricultural productivity. The study believed that the Salam provide an alternative solution to agricultural finance since its contains, interest free repayment, manipulations free from gambling, efficient credit supply, price stabilization free corruption, source of employment/eradication of poverty as well as driver towards economic growth and development. The overall recommendation suggested that Muslims and Non-Muslims alike in Nigeria especially those into farming shall as much as possible made to embrace Salam, in order to benefit optimally from this new economic and financial phenomenon that is cutting across religious affiliations, cultural differences and geographical boundaries.
\end{abstract}

Keywords: agri-business, agriculture, Islamic finance, Nigeria, rural farmer, Salam.

JEL Classification: Q10, Q13, Q14.

(C) The Authors, 2018. This article is published with open access at Sumy State University.

\section{Introduction}

Agriculture remains the basic sector of the economy which provides food for population, raw materials for industries, employment for the unemployed and foreign earnings for the state, among other important contributions. The connection between agriculture and economic growth is therefore very clear (Lamido, 2014). Meanwhile the role of finance in the general over haul of the agricultural system particularly as it concern enhance greater and more efficient production cannot be overemphasized. Thus, with the level of adverse effort in the rest on the world's economy has a new method of financial agriculture; this is a kind of benevolent means of financing that had without any iota of doubt contributed immensely to increasing food production several decades ago and will of course do the same in our contemporary age (Odeduntan, 2015).

Salam is a forward sale of commodity (originally an agricultural product) and should be presented on a specific future date and fourth dimension. Also, Salam is a sale of an object which is not available at the time of the conclusion of sale but will be rendered in the future on a determined future date. The price is yet to be 
paid instantly after beginning of the contract (Muhammad, Chong, Firdaus, Abdullah and Anderson, 2007, cited in Mohammed, 2015). This system of financial is the divine method that is interest-free, ethnical and benevolent it is the Sharia system of finance or Islamic finance which is established on the fundamental principles of Islam covering the jurisprudence of transaction. Although, Islamic finance is a nascent industry it has become a household name in the recent time. It avoids the agricultural systems the opportunity of growing and expanding to such a great effort of making agriculture a main stay of economy. The Islamic system of financial introduces to farmers a robust financial technique that may help them increase their productivity without going through the conventions of the system (Riba) that keeps them in perpetual penury owing to injustices that characterizes the system (Odeduntan, 2015).

It is apparent that most farmers are rural dwellers whose objective of going into the profession basically satisfies their immediate needs. They therefore have limited capacity to generate revenues beyond the needs of their families if it is left for them (Odeduntan, 2015). Despite the importance of agriculture to Nigerian economy, however, there is a lack of necessary credit facilities to promote the sector. Several researchers reveal that introduction of alternative credit facility (Salam) is necessary (Dandago, et al., 2013). In a nutshell, it is hopeful that this study will contribute to academic learning and further research, knowledge dissemination as well as the practice of Islamic mode of financing agribusiness and agriculture in Nigeria and elsewhere. Islamic finance providers may use this study to perceive behavior of farmers on patronage. Farmers may also use this study to have an insight of Islamic mode of financing and investment operation, the products available for farmers benefits as well as the procedure to reap those benefits. Government may also use this study in policy formulation and evaluation of various forms of financing.

\section{Islamic perspective on agribusines and agriculture}

Islamically and conventionally, the importance of agriculture can never be overemphasized. The Shari'ah compliance (halal means) issue will never be attained unless it is critically assessed from the Shari'ah perspective, the importance of trust amana, justice and equity adalah are immensely needed in any fiduciary contract such as Share cropping Muzara'ah (Yahuza and Idris, 2015). Hence, Allah the Almighty enjoins mankind to seek all the bounties of the material resources endowed in this world in a halal and purified manner.

"O Mankind! Eat of that which is lawful and good on earth, and follow not the footsteps of Satan. Verily, he is to you an open enemy. For he commands you only what is evil and sinful, and you should say against Allah what you do not know" (Q: 2, V: 168-9). In view of the above exposition, there is the need to assess the local practice of Bai' Salam from the Islamic perspective as conducted by rural farmers in Bauchi state of Nigeria.

Agriculture known as (filahah or zira'ah) in Arabic language and in Islamic teaching hails a sector of economy of great importance that shall not be neglected. Indeed, there are many verses from the al-Qur'an as well as the traditions of the Prophet of Islam (SAWA) which emphasize the importance of agriculture (Borhan and Aziz, 2009 cited Yahuza and Idris, 2015). Many Qur'anic verses stress the importance of agriculture in the following verses: "It is He who has spread out the earth for His creatures. Therein are fruit and date palms, with spatters and husked corn and scented herbs. Then which of the favours of your Lord will you deny?" (Q: 55, V: 10-13). And also; "Then let man look at his food, how we pair forth water in abundance, then we split the earth into fragments and produce therein corn and grapes and nutritious plants" (Q: 20, V: 24-28".

The following verses affirm the importance of land, water and seeds in food production as: "And a sign for them is the dead land. We give it life, and We bring forth from it grains, so that they eat thereof. And We have made therein gardens of date-palms and grapes, and We have caused springs of water to gush forth therein, so that they may eat of the fruit thereof, and of what their hands made. Will they then give thanks not? Glory be to Him (The Almighty Allah) Who has created all the pairs of that which the earth produces, as well as themselves, and of that which they knew not" Q: Yasin, V: 33-6).

The Prophet of Islam (SAWA) emphasizes on agricultural production and commands Muslims to engage in it. He says: "When a Muslim plant or cultivates a crop, no bird, animal or human being eats from it without its being accounted as a charity (Sadaqah) for him" (Sahih Muslim: 1553, p. 435 cited in Yahuza and Idris, 2015). 
Furthermore, Murtala (2012) accurately observes that the Prophet of Islam (SAWA)' emphasis comes to stress on special aspects like irrigation and redemption' of a barren land to enhance agriculture where $\mathrm{He}$ says: "Whoever brings dead land to life, for him is reward in it and whatever any creature seeking food eats of it, shall be considered as charity (Sadaqah) for him" Musnad Ahmad, Vol. 2, Hadith No. 14271, cited in Yahuza and Idris, 2015).

It is on records that, Ridhwan (2011) and Ridhwan (2013) infer that Islam views agriculture as a collective obligation (Fard al-Kifayah) upon the entire community, this implies that, a number of people from Muslim community must embark on agricultural production in order to ensure ample food supply for the Muslim society at large. The production function was based on the concepts of earnings livelihood (al-Rizq) as well as lawful (halal) and umlawful (haram) by promoting the former and prohibiting the latter. The lawful contracts such as: Ijarah, Salam, Muzara'ah, Musaqah, Mugharasah, Ju'alah and barter (exchange) contract with condition of equality in quality and quantity, whereas the prohibited are the Muzabanah, Muhaqalah, Mu'awamah and selling of fruits before it is mature, all these have been reported in many authentic ahadith with the exception of Ariyyah.

\section{Islamic financial products for agribusiness and agriculture}

There are many products in Islamic finances that dominate Islamic financial institutions especially in the modern times. Some of them are equity based while some others are sale/trade based. Yet some others are structured along the lease based agreements. Whichever method that is adopted, the basic principles of Shari'ah underlying each of these products must be followed to the latter. This explains why in most cases Shari'ah scholars and Islamic finance professionals are consulted to ensure that the products so chosen are Shari'ah compliant and are not in any way contain elements of unfairness, inequity and injustice (Odeduntan, 2014).

Besides, it must be mentioned that some of these products are originally structured to favor farmers and agricultural boost with a view to help farmers in achieving efficiency and high productivity; some others are adaptable to suit the purpose of agriculture and farmers. Examples of sale or trade based products include products such as Murabaha, Musawama, Salam, Istisnah and likes. Lease based only includes Ijarah while equity based products are Musharakah, Mudharabah, Mushara Mutanaqisah (i.e. Diminishing Musharakah), Musaqat, Muzara'ah and Mugharasah. All these can be used for one or the other segment of agriculture (Odeduntan, 2014).

The popularity of this practice leads us to believe that the price received in advance might have met both the productive and consumption requirements of the cultivators. Fixation of three years as the time of delivery suggests that money was also required for fixed investment like improvement of land and growing gardens. In the context of Syria, digging of wells and providing irrigation facilities could also be a possible purpose of the request for advance payment. Against the backdrop of the forgoing, one illustration of the applications of some of the aforementioned products may suffice. Salam may be used for financing farming activities. Ayub (2007) posited that Salam was approved by the Prophet of Islam (SAWA) as part of Shari'ah oriented public policy. The most underlying cause of initiating Salam contract was to aid the small scale farmers (poor farmers) who lack money to sustain crops and take on their daily needs before the time of harvest. Meanwhile, "Salam" allows them (farmers) to sell forward their expected farm produce for immediate cash and defer delivery of the produce to its buyer for specific future time.

Salam can simply be described as forward sale. According to the AIMS-UK Islamic banking and finance, Salam is defined as: "a sale whereby the seller undertakes to supply some specific goods to the buyer at a future date in exchange of an advanced price fully paid at spot". This product portrays that the cash is fully provided for while the supply of the purchased goods is deferred. There are usually four parties to this agreement. There are the buyer, the seller, the purchased commodity and of course the cash price. In Arabic terminology, the buyer is referred to as "Rabb-as-Salam" and the seller is often called "Muslam ilaih". The purchased commodity is known as "Muslam fih", while the cash price is term as "Ra's-ul-mal".

A cursory look at the principles of Islamic jurisprudence with respect to Salam will reveal that Salam on the outlook refers to a financing in which a seller of a product agrees and undertakes to sell the commodity to the buyer at an agreed future date in exchange for a price fully paid in advance or on spot basis. The legality for this type of financing under Islamic law can be found in Qur'an, Chapter 2, Verse 282 which provides that: "O you who believe when you deal with each other in transaction involving future obligations in a fixed period of time reduce them to writing, let a scribe write down faithfully as between the parties". 


\section{Virtues of Islamic financing arrangements}

Islam is a comprehensive way of life. It is very comprehensive because it deals with each part and parcel of human life. It embraces worship, individual attitude and conducts as well as social norms and laws, whether political, economic, and so on and so forth (Abbas, 2014). Hence, the factors of production are meant to suit human desires as permitted by Islamic belief that Allah (SWT) created everything before man and for man (Q2:22) and Hadith 224 of Khan (1994); and man is encouraged by Allah (SWT) to be Muhsinun, one who transform things from bad to good (Q2:11); good to better and benefit from it (Q5:3, 16:90; 18:110; and 45:15). Angels pray for good doers and curse evil doers, Hadith 522 in Khan (1994). Impliedly, prior to the global call for entrepreneurship in the proceeding and current millennium, man had been enjoined to work, do good and better things in Islam.

Under the Islamic principles, it defines the ways and manners in which Muslims should conduct their lives and affairs as prescribed in the Holy Qur'an and the Sunnah of the Prophet of Islam (SAWA). Man in Islam is Allah's vicegerent on earth; in the Qur'an 2:30 stated that: "Behold, thy Lord said to the angels: I will create a vicegerent on earth ..." (See also Q6: 165, 7:74, 35:39, 38:26, 7:10). In relation to business and Islamic banking and finances, the way and principle in which they should be conducted are also defined in Islam. Hence, Aliyu (2015) offered some virtues that are to be reaping in the Islamic financing arrangements as below:

1. Based on the principles of socio-economic justice, brotherhood, kindness, fairness, etc. (Q4:135, 5:2, $7: 157)$;

2. Free from interest, equity and PLS arrangements stimulate agriculture and SMEs to create employment and real wealth of the society through socially and ethically compatible investments $(\mathrm{Q} 2: 275,3: 131$, $4: 161$, etc);

3. Devoid of Gharar (uncertainty), Islamic banking products remove fear of insolvency and unlimited liability (Q6:151-152);

4. Specific/critical needs of agriculture and SMEs are taken care off as Islamic banks provide financing by coming in as: Traders (Mudaraba, Musharaka);

5. Better business ethics as Islamic banks only entertain economically viable business projects-prohibition of harmful commodities such as liquor, pork, and pornography (Q5:90, 6:151-152);

6. Extolling the virtues of ethical financing arrangements;

7. Unlike in conventional financing, risks are shared equitably among parties to a contract as net positive or negative outcomes are shared between money capital and human capital;

8. Agriculture and SMEs, Islamic banks and other savers can observe their modest share of loss without causing disruption/dislocation to the financial system through loan delinquencies or bankruptcy;

9. Results in overall economic stability, not exposed to the extreme i.e. between booms and recessions/depressions;

10. Promotes greater harmony, cooperation and peaceful coexistence in the society; and

11. Abiding by the injunctions of the Almighty results in blessing in this world and the hereafter.

\section{Materials and method}

Bauchi state is selected for this study and the choice was deliberate because the state is endowed with large bodies of water, which facilitate agricultural and other productivity, for example, rivers Jama'are and Gongola cut across some local government areas in the state. Added to these are dams like Gubi Dam in Bauchi local government area, Tilden Fulani in Toro local government area and Maladumba in Misau local government area. These in one way or the other are meant for irrigation and other productive activities. The study area spans two vegetation zones namely the Sudan Savannah and Sahel Savannah. Adaba (2006) conceived that the Bauchi state lies between latitude of 9.3 and 12.3 North of the equator and longitude 8.5 and 11 East of the Greenwich Meridian. It is bordered by seven states, Kano and Jigawa to the North, Taraba and Plateau to the South, Gombe and Yobe to the East, and Kaduna to the West. It occupies a total land area of $549,259.01$ sq. $\mathrm{km}$, representing $5.3 \%$ of the landmass of Nigeria.

This study was carried out with a strong view of determining the perceptions on the possible benefits that can be derive by farmers from the new alternative ethical finance as well as the rate of farmers' awareness about the Salam Islamic mode of financing agribusiness and agriculture in Bauchi state. The study conducted in Bauchi state collected primary data from three (3) selected local government areas to represent the three (3) geo-political senatorial districts of Bauchi South, Bauchi Central and Bauchi North in the state. In view of 
the aforesaid, the study was conducted in Dass, Darazo and Katagum local government areas of Bauchi state. Two districts were selected from each local government area through multistage sampling techniques and some certain 10 villages were randomly selected. In all the villages selected, 150 respondents were selected using simple random sampling (15 respondents/village). This gives a total of one hundred and fifty (150) respondents.

The research work adopted a cross sectional research design and quantitative method approach, the data was collected using questionnaire method that was acknowledged for Islamic mode of financing agribusiness and agriculture, because it took into cognizance the use of standard data allowing easy comparison and respondents' views could be captured with minimum effort and cost. The interview strategy could not be adopted since the number of respondents was rather large and cannot be managed with finite time and cost. Case study is a good strategy, but was not selected after considering the time needed to complete the research and weak possibility of generalization. Experiment research was not selected due to its unsuitability to this research, which is not on natural science.

The questionnaire was validated for its contents and face validity by the financial and agricultural experts. Further, experts in the field of test and measurement and language validated the questionnaire which ensures its consistency, language appropriateness and clarity. The study adopted the works of De-Noble et al. (2007) which also had a reliability of 0.86 of Cronbach's alpha. The data collected method adopted was the face to face survey method using the questionnaire. Out of the 150 questionnaires distributed only 118 were filled and returned. The data analysis technique used for the analysis is the multiple regression analysis using STATA 14.

\section{Conceptual framework}

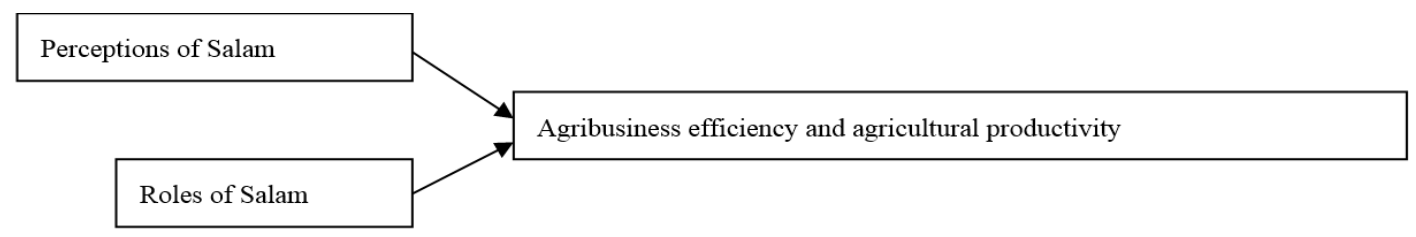

Source: researchers' conception.

\section{Results and discussion}

The given data regarding this particular research situation are characterized with some statistical measures for the purpose of estimation or comparison with similar data or making inference about the sample population. Therefore, 118 questionnaires were filled and returned out of the 150 administered questionnaires, although one of the questionnaires was discarded as it was not filled property and the total of 117 questionnaires was used to analyze the results of the research finding. Accordingly, about sixty percent (60\%) of the population that responded to the questionnaires were male respondents whereas the remaining fourty (40\%) percent were female respondents. The age bracket of 31-40 years of age had the highest responses of about fourty seven percent (47\%), while the other age bracket of 21-30 were having twenty seven percent (27\%), the age bracket 41-50 years of age respondents remained twenty two percent (22\%) and the 51 and above age bracket respondents form the three percent (3\%). The Muslims in the population were about $82 \%$ while the Christian make up of sixteen (16\%) of the research population, other religions constitute the added percentage which is two (2\%).

Table 1. Regression analysis of data

\begin{tabular}{|c|c|c|c|c|c|c|}
\hline AA & Coef. & Std. Err. & t. & P> $[\mathrm{T}]$ & \multicolumn{2}{|c|}{ (95\% conf. interval) } \\
\hline PS & 0.921867 & 1.659296 & 0.8 & 0.423 & -.1350307 & .3194041 \\
\hline AS & 0.16975 & 0.0685999 & 2.47 & $0.015^{*}$ & .0338546 & .3056461 \\
\hline Cons & 1.659296 & 0.4277086 & 3.88 & 0 & .8120083 & 2.506583 \\
\hline
\end{tabular}

Source: field work outcome (2017); authors computation; STATA 14.

Notes: $* 5 \%$.

Hence, while deducing from Table 1 above that bordered on the regression analysis of the data. The findings of the research show a clear positive relationship between perceptions of Salam (PS) and the agribusiness efficiency and agricultural productivity (AA). Although the results show a positive relationship between PS and AA but there is no influence between PS and AA because of the P value which is higher than $10 \%$, but the results also shows that there is strong influence of the Roles of Salam (RS) in boosting agribusiness effi- 
ciency and agricultural productivity in the study area. On the basis of the outcome of this research study, the statistical test disproves the assumption of farmers' perception level to be on the high level but rather revealed a divergent view that there is an unhelpful level of respondents' perception of Salam as an alternative ethical mode of financing agribusiness and agriculture. On another dimension, the result suggests that there are needs for the nitty-gritty of this new ethical mode of financing and investment to be made known to our rural farmers so as to help boost their agribusiness efficiency and the agricultural productivity in Bauchi state in particular and the country in general.

From the point of view of the farmers, Bai' Salam (Forward sale) might be a preferable way of taking financing as compared to a loan with interest, because first, it did not make an increase in cost as interest did and, second, it saved them from the hardships and the risk involved in marketing. It is not certain whether the institutions of Bai 'Salam (Forward sale) brought about any change in the role of intermediaries in the rural economy. It is certain that it paved the way for a direct relationship between the grower and the trader in the city, who generally was the supplier of funds. As the buyer in a free market would always choose to purchase at a price which gives him good income on resale on the stipulated date and during the supply season, Bai Salam (Forward sale) could prove an effective means of stabilizing the price at a moderate level during periods of seasonal fall in demand. And because the Shari'ah does not allow resale of Salam goods before they are actually transferred to the buyer, it would protect the prices from exposure to speculative rise and stabilize them at a lower level. Contrary to this, financing production/inventory building through loans with interest automatically increases the cost of production/stocks. This increase is further shot up by speculative transactions for anticipated brisk trade seasons. Salam provides a price hedge for the buyer and protects both the buyer and the seller from the respective risks of revenue and price-indexed debts. It is less incentive on the part of the seller to transfer any additional risks to the buyer by manipulating his reported revenues, as could happen in the conventional commodity forward market. Part of the variation in revenue has been already transferred to (and accepted by) the buyer in the form of a predetermined price, and the other (quantity) part is contractually fixed.

\section{Conclusion and recommendations}

To sum up all therefore, Salam has a vast potential in financing the productive activities in crucial sectors, particularly agriculture, agro-based industries and the rural economy as a whole for financing agriculturists/farmers, commodity operations of public and private sectors and other purchases of homogeneous goods. As the study assesses the potentials of Salam Islamic mode of financing the development of agribusiness and agriculture in the modern economy, it's equally explores the nature and benefits of Salam in financing agribusiness and agriculture leading to the generation of employment, economic growth and development. The study in the process establishes that access to finance is a major constraint bedeviling the development of agribusiness and agriculture, not only in Bauchi state, but in the country at large. Though the Salam Islamic mode of financing and investment have the capacity to grow and develop agribusiness and agriculture in Bauchi state, the country as a whole and over the world.

As a forward contract, this study believed that the Salam mode of financing gives the buyer the required hedge against possible future price increases. It gives the seller the required price protection and does not involve any predetermined cash debt on either party. Being that one can get financing directly from buyers without involving any intermediary, the study suggested that banks can likewise participate as a buyer on a Salam basis in a competitive environment. For this reason, a Salam contract can bring about the benefits of a swap without the involvement of interest and at a lower cost. The transaction costs associated with a Salam contract are likely to be much lower than those of a swap. A swap is an agreement whereby one party replaces one cash flow (or commitment) by another that is indexed to some price or interest rate. A country that obtains a loan, for instance, exchanges its debt obligation with another firm that undertakes to assume the obligation in exchange for payments based on the price of some commodity. In spite of the expected benefits of swap agreements, they may not be among the best instruments, for the overall transaction costs associated with them may be very high.

The research study further recommended that the Central Bank of Nigeria and all other regulatory authorities should simply provide the guidelines and requirements for establishment of Islamic ethical financial windows in Nigeria, so that Muslims and Non-Muslims alike in Nigeria especially those engaged into farming shall as much as possible made to embrace Salam, in order to benefit optimally from this new economic and financial phenomenon that is cutting across religious affiliations, cultural differences and geographical 
boundaries. In addition, the paper recommends that the community, religious, traditional rulers, well-to-do in the society, civil servants and other individuals should rise to the call to create awareness and promote fundbased Shari'ah compliant investment arrangement-Salam-in their communities.

\section{References}

1. Aliyu, S.U.B. (2014). Potentials of Islamic Banking in the Development of Micro and Macro Enterprises: An Exposition. Proceedings of the $1^{\text {st }}$ International Conference by International Institute of Islamic Banking and Finance held at Bayero University Kano (Nigeria) between $17^{\text {th }}-19^{\text {th }}$ April.

2. Abbas, U.S. (2014). Relevance of Islamic Banking to Socioeconomic Development in Nigeria. Proceedings of the $1^{\text {st }}$ International Conference by International Institute of Islamic Banking and Finance held at Bayero University Kano (Nigeria) between $17^{\text {th }}-19^{\text {th }}$ April.

3. Adaba, T. (2006). Bauchi State: A Historical Perspective. Abuja: Trim Communication Limited.

4. Ayub, M. (2007). Understanding Islamic Finance. West Sussex: John Wiley and Sons Limited.

5. Dandago, K.I., Muhammad, A.D., and Oseni, U.A. (2013). Essentials of Banking and Finance in Nigeria. Kano: Benchmark Publishers Limited.

6. De-Noble, A., Galbraith, C.S., Singh, G. and Stiles, C.H. (2007). Market justice, Religious orientation and Entrepreneurial attitudes: An empirical study. Journal of Enterprising Communities: People and Places in the Global Economy, 1(2): 121-134.

7. Jaffer, M.A. and Musa, R. (2013). Determinants of Attitude towards Islamic financing among HalalCertified Micro and SMEs: A Proposed Conceptual Framework. International Journal of Education and Research, 1(8).

8. Khan, M.M. (1994). Summarized Sahih Al-Bukhari Arabic - English. Riyadh: Dar-us-Salam Publishers and Editions.

9. Khan, M.M. (1996). The Noble Qur'an: English Translation of the Meanings and Commentary. Madinah: King Fahad Complex for the Printing of Holy Qur'an.

10. Lamido, A.A. (2014). Financing Economic Development in Nigeria: The Role of Islamic Banks. Proceedings of the $1^{\text {st }}$ International Conference by International Institute of Islamic Banking and Finance held at Bayero University Kano (Nigeria) between $17^{\text {th }}-19^{\text {th }}$ April.

11. Mohammed, A.I. (2015). Application of Salam financing in Agricultural finance in Nigeria. Proceedings of the $2^{\text {nd }}$ International Conference by International Institute of Islamic Banking and Finance held at Bayero University Kano (Nigeria) between $28^{\text {th }}-29^{\text {th }}$ April.

12. Murtala, A. (2012). The Marketing of Agricultural Produce in an Islamic Agricultural Economy. World Journal of Islamic History and Civilization. Available online from http://idosi.wjihc.2012.2.2402. Retrieved on $17^{\text {th }} / 05 / 2017$.

13. Odeduntan, A.K. (2015). Financing Agriculture through Islamic Finance. Proceedings of the $2^{\text {nd }}$ International Conference by International Institute of Islamic Banking and Finance held at Bayero University Kano (Nigeria) between $28^{\text {th }}-29^{\text {th }}$ April.

14. Ridhwan, M.A.A. (2011). Opportunity for Agricultural Entrepreneur in Developing Agro Initiative in Islamic Banking in Malaysia. The Journal of Animal and Plant Science, 290-302.

15. Ridhwan, M.A.A. (2013). A Review of Islamic Banking Products offered by Agro Banking between 2008 and 2012. Journal of Emerging Issues in Economics, Finance and Banking (JEIEFB), 1(4).

16. Yahuza, B.S. and Idris, M. (2015). An Assessment of the Shari'ah compliant Muzara'ah and Local Cropping Practice in Kano State, Nigeria. Proceedings of the $2^{\text {nd }}$ International Conference by International Institute of Islamic Banking and Finance held at Bayero University Kano (Nigeria) between $28^{\text {th }}$ $29^{\text {th }}$ April. 